\title{
Measuring Dimensions Of Brand Personality
}

\author{
Gatot Wijayanto $^{1)}$ \\ 1) Lecturer of the Management Program in the Faculty of Economics, Riau University, Kampus Bina Widya \\ Simpang Baru, Pekanbaru, 28293, Riau Province / Doctoral Student of Management Science Program The \\ Faculty of Economic and Business, Padjadjaran University \\ E-mail: gatotwijayanto01@gmail.com
}

\begin{abstract}
The purpose of this paper is redefining constructs Brand Personality by analyzing the concept and measurement of Brand Personality. Brand personality study be undertaken by identifying and measuring the dimensions of Brand Personality.

The problem raised in this paper is composed of brand personality dimensions consist of personality characteristics or different from each measurement (Aaker, 1997; Caprara, 2001; Azoulay and Kapferer, 2003; Guzman and Sierra, 2009; Geuens, et.al. 2009; Muniz and Marchetti, 2012). The approach used in this paper by comparing the concept of personality and measurement of the dimensions of the brand of several researchers who has been tested in their research .

Implications of the results of this study will provide the benefits of measuring the dimensions of some of the research which will result in the identification and measurement operation of each dimension of Brand Personality. Original contribution of this paper will redefine the dimensions of Brand Personality constructs.
\end{abstract}

Keywords: Dimensions of Brand Personality, Measuring and Political Party

\section{Introduction}

In the context of relationship with Brand Personality, Siavoshani, et al, (2014: 1547) claimed that the Brand Personality has become one of the most popular topics for several decades, because we can provide insight to distinguish the brand, developing emotional characteristics of a brand and increasing the personal concept of a brand for consumers. This is consistent with the review of the literature on the concept of brand personality which refers to a journal written by Aaker (1997); Geuens, Bert \& Wulf (2009); Milas \& Mlačić (2007); Jana, et.al (2014); Arora \&Stoner (2009); Azoulay \& Kapferer (2003); dan Bosnjak, et.al, (2007).

With respect to with the context of Brand Personality, Maehle, et al, (2011: 290) said also that the Brand Personality has become a popular topic in the marketing literature for more than 50 years, as has been done by many researchers for example (Martineau, 1957; Dolich, 1969; Hamm and Cundiff 1969; Aaker, 1997; Wee, 2004; Freling and Forbes, 2005a, 2005b; Govers and Schoormans, 2005; Ramaseshan and Tsao, 2007). However, most of the existing literature related to Brand Personality has focused on defining the construct as quoted by Aaker, (1997); Azoulay and Kapferer, (2003), for the development of scale and redefinition as done by Aaker, (1997); Aaker et al., (2001); Austin et al., (2003) in Maehle (2011: 290). And who studied the effects of Brand Personality variables related to the other brands made by the researchers for example (Siguaw et al., 1999; Freling and Forbes, 2005a; Govers and Schoormans, 2005; Ramaseshan and Tsao, 2007) in Maehle (2011: 290 ). Only some of the investigation that studies the nature of the brand personality and identify the source as performed by maehle , (2008; maehle supphellen and , (2008).

To study the measurement of the dimensions of Brand Personality, reference is taken from the dimensional model Brand Personality (Big Five Brand Personanlity) proposed by Aaker (1997); Bosnjak, et.al., (2007); Geuens, et.al (2009); Caprara (2001) in Guzman and Sierra (2009). 


\section{The concept of Brand Personality}

Brand personality is a key component of the brand and control of Brand Equity as quoted from Keller, (1993) in Sweney and Brandon, (2006: 2). While according to Batra, Lehmann, \& Singh, (1993) in Sweney and Brandon, (2006: 645) defines brand personality as a personality traits usually associated with humans in which consumers consider the brand to have.

According to the American Marketing Association, the brand is "a name, term, sign, symbol, or design, or a combination of them, intended to identify the goods and services of one seller or group of sellers and to differentiate them from competitors" (AMA 2010) in Jana, et al, (2014: 3). Another definition of a brand (brand) proposed by Srivastava, Fahey, and Christensen (2001); Crane Matten and Moon (2008) in Jana, et al, (2014: 3) that the brand is a means to meet all the different stakeholders of the companysuch as customers, buyers, or civil society organizations.

Furthermore Kapferer (2007) in Jana, et.al. (2014: 3) states that the brand is a set of perceptions. While according to Keller (2008) and Ramello (2006) in Jana, et al, (2014: 3), claimed trademarks are the means of protection and is used to identify and distinguish the products and services of the company from its competitors.

Based on the definition of the brand has been described, it can be concluded that the brand is a tool used by the company in the form of entity names, the term symbol, design, mark as a set for identifying the company's products.

Personality traits appear to be associated with a brand indirectly through the attributes associated with the product, product category associations, brand name, symbol or logo, advertising style, price, and distribution channels (Batra, et.al., 1993 in Muniz and Marchetti, 2012: 171). Perception of human personality traits inferred based on individual behavior, physical characteristics, attitudes and beliefs, and demographic characteristics.

Based on such information, it can be declared that the character's personality is the soul of the brand that serves to communicate and highlight the brand through product attributes such as brand name, logo, symbol, advertising, pricing and distribution channels.
Further definitions relating to the Brand Personality is as follows:

Brand personality is defined as the set of human characteristics associated with a brand (Aaker, 1997: 347). This definition is used also by: Michael Bosnjak, 2007; Maggie, et al, 2007; Guzmin Francisco and Vicenta Sierra, 2009. (Brand Personality is defined as the set of human characteristics associated with a brand). Azoulay and Kapferer (2003: 151), brand personality is the set of human personality traits that are both applicable to and relevant for brands. Sweeney and Brandon (2006: 645), Brand personality is the set of human personality traits that correspond to the interpersonal domain of human personality and are relevant to describing the brand as a relationship partner. According to Lannon (1993) in the Sung and Kim (2010: 641), Brand personality is beneficial to marketers and consumers. For marketers, a brand's personality is an integral component of a brand's image and equity, and it is related to the brand's value in the consumer's mind. And Batra, Lehmann and Sigh (1993) in Muniz \& Marchetti (2012; 171), define brand personality as how a consumer understands the brand in dimensions that typically capture a person's personality.

Based on the definition of the concept of Brand Personality is defined similarly to relate to the characteristics of a person's personality typikal relevant to the brand.

Definition brand personality by Gelder, S.V (2005), "Brand personality is developed to enhance the appeal of a brand to consumers", and then according to Crainer dan Dearlove (2003), "Brand personality is a brand acquires a character through communication about the brand and experience of the brand and those persons identified with the brand". While according to Keller (1993), "Brand personality is the human characteristics or traits that can be attributed to a brand".

Based on some of the opinions can be declared that Brand Personality is part of the nature and character of consumer psychology applied in the brand so that there are personal closeness between the consumer and the brand of a product.

Thus Brand Personality is a way that aims to increase the attractiveness of the brand by giving the characteristics of the brand, which can be obtained through communication, experience, relationships between individuals as well as of those who introduced the brand itself. 


\begin{tabular}{|l|l|}
\hline \multicolumn{1}{|c|}{ Author } & \multicolumn{1}{c|}{ Definition } \\
\hline $\begin{array}{l}\text { Ramaeseshan and Tsao (2007: } \\
460)\end{array}$ & $\begin{array}{l}\text { Brand personality as the soul of a brand that originates } \\
\text { from the brand's characteristics and marketing } \\
\text { communications. }\end{array}$ \\
\hline $\begin{array}{l}\text { Azoulay \& Kapferer (2003: } \\
\text { Brand personality is the set of human personality traits that } \\
\text { are both applicable to and relevant for brands. }\end{array}$ \\
\hline Aaker (1997:347) & $\begin{array}{l}\text { Brand personality is defined formally as the set of human } \\
\text { characteristics assoiciated with brand. }\end{array}$ \\
\hline $\begin{array}{l}\text { Park (1986) in Aaker (1997: } \\
348)\end{array}$ & $\begin{array}{l}\text { Perceptions of human personality traits are inferred on the } \\
\text { basis of an individual's behavior, physical characteristics, } \\
\text { attitudes and beliefs, and demographic characteristics. }\end{array}$ \\
\hline $\begin{array}{l}\text { Plummer (1985) in Aaker } \\
(1997: 348)\end{array}$ & $\begin{array}{l}\text { Perceptions of brand personality traits can be formed and } \\
\text { influenced by any direct or indirect contact that the } \\
\text { consumer has with the brand. }\end{array}$ \\
\hline $\begin{array}{l}\text { Batra, Lehmann, \& Singh } \\
(1993)\end{array}$ & $\begin{array}{l}\text { brand personality is a consumer's evaluation of a brand on a } \\
\text { pattern of traits that are typically used to describe a person's } \\
\text { personality. }\end{array}$ \\
\hline
\end{tabular}

Based on the concept that there turns Brand Personality Brand Personality concept is defined differently by Aaker (1997) as a set of human characteristics that have meaning as "The fundamental dispositions and traits of humans" (Merriam-Webster's Collegiate Dictionary, 10th ed,), by Azoulay \& Kepferer (2003) as a set of human personality traits that have meaning as "Human personality can be defined as a dynamic and organized set of characteristics possessed by a person that uniquely influences his or her cognitions, motivations, and behaviors in various situations" (Wikipedia.com) and Ramaeseshan \& Tso (2007) as the soul of $\boldsymbol{a}$ brand that have meaning as "A brand that has soul shares a passion and motivation with its customers" (Ayesha Mathews -Wadhwa).

Based on the definitions above, this paper proposed a redefinition of the concept of Brand Personality is as a collection of a set of characters, character and properties of the fundamental human uniquely associated with the brand of a product that has a soul which comes from the characteristics of the brand and marketing communications for share the passion and motivation with customers.

\section{Measuring Dimensions of Brand Personality}

Brand personality has a very large role in the marketing of a product, so that research on the dimensions of brand personality as a reliable measuring instrument becomes an important agenda. Through his research Aaker (1997) acquire five structural factors that made the concept of brand personality dimensions. These dimensions are Sincerity, Excitement, Competence, Sophistication, and Rudggeness.

In the development of the concept of dimensional measurements of Aaker's Brand Personality (2007) contradicted by other researchers. The first criticism is done by Azoulay and Kapferer, (2003); Bosnjak, et.al., (2007) who found Brand Personality can also include some other characteristics (such as age, gender, etc.) other than the personality. The second criticism presented by Austin, et al, (2003) concerning the non-generalization of the structure factor for analysis at the level of the respondents to a specific brand or specific product categories. The third criticism related to the non-imitation of the five cross-cultural factors (Azoulay and Kapferer, 2003).

Berikut tabel di bawah ini akan menjelaskan pengukuran skala dimensi Brand Personality menurut Aaker (1997), Bonsjak (2007), Geuens, et.al., (2007), dan Caprara et.al (2001) dalam Guzman \& Siera (2009) beserta alat ukurnya, yaitu :

The following table below will explain the measurement scale dimensions Brand Personality according to Aaker (1997), Bonsjak (2007), Geuens, et al, (2007), and Caprara et.al (2001) in Guzman and Sierra (2009) and measuring instruments, that is:

Dimensions of Brand Personality Measurement Model by Aaker (1997) 


\begin{tabular}{|l|l|l|l|l|}
\hline \multicolumn{1}{|c|}{ Sincerity } & \multicolumn{1}{|c|}{ Excitement } & \multicolumn{1}{c|}{ Competence } & Sophistication & \multicolumn{1}{c|}{ Rudgeness } \\
\hline Down to Earth & Daring & Reliable & Upper Class & Outdoorsy: \\
\hline Honesty & Spirited & Intelligent & Charming & Tough \\
\hline Wholesomeness & Imaginative & Successful & & \\
\hline Cheerfulness & Up-to-date: & & & \\
\hline
\end{tabular}

Dimensions of Brand Personality Measurement Model by Bosnjak, et.al., (2007)

\begin{tabular}{|l|l|l|l|}
\hline \multicolumn{1}{|c|}{ Drive } & \multicolumn{1}{c|}{ Conscientiousness } & \multicolumn{1}{c|}{ Emotion } & \multicolumn{1}{c|}{ Superficiality } \\
\hline $\begin{array}{l}\text { Excited, like the } \\
\text { challenge, boring }\end{array}$ & $\begin{array}{l}\text { Competence, } \\
\text { presentable, reliable }\end{array}$ & $\begin{array}{l}\text { Lovingly, friendly, } \\
\text { sensitive }\end{array}$ & $\begin{array}{l}\text { Selfish, arrogant, } \\
\text { cynical }\end{array}$ \\
\hline
\end{tabular}

Dimensions of Brand Personality Measurement Model by Geuens, et.al., (2009)

\begin{tabular}{|l|l|l|l|l|}
\hline Responsibility & \multicolumn{1}{|c|}{ Activity } & Agreessiveness & \multicolumn{1}{c|}{ Simplicity } & \multicolumn{1}{|c|}{ Emotionality } \\
\hline $\begin{array}{l}\text { Down to earth, } \\
\text { stabilized, } \\
\text { responsible }\end{array}$ & $\begin{array}{l}\text { Actively, } \\
\text { Dynamic, } \\
\text { innovative }\end{array}$ & $\begin{array}{l}\text { Aggressive, } \\
\text { naughty }\end{array}$ & $\begin{array}{l}\text { Usual (normal), } \\
\text { simple }\end{array}$ & $\begin{array}{l}\text { Romantic, } \\
\text { sentimentally } \\
\text { (sensitive) }\end{array}$ \\
\hline
\end{tabular}

Dimensions of Brand Personality Measurement Model by Caprara, et.al., (2001) in Guzman \& Siera (2009).

\begin{tabular}{|l|l|l|l|l|}
\hline \multicolumn{1}{|c|}{ Energy } & Agreeableness & Conscientiousness & \multicolumn{1}{|c|}{ Emotional } & \multicolumn{1}{c|}{ Openness } \\
\hline Happy & Authentic & Reliable & Level-headed & Sharp \\
Determined & Cordial & Constant & Optimistic & Creative \\
Dynamic & Generous & Efficient & Serene & Innovative \\
Energic & Loyal & Scrupulous & Self-confident & Modern \\
Enterprising & Sincere & Responsible & Solid & Original \\
\hline
\end{tabular}

Based on the measurement scale of brand personality dimensions described by these table above, it can be stated that there are similarities between the concepts proposed by Aaker (1997); Bosnjak et.al, (2007); and Geuens, et al, (2009), although different in name.

Basically brand personality can use common characters owned by humans as a dimension that can be a measuring tool brand personality, These character may include gender, age, social class,

\section{Reference}

Aaker, Jennifer L., (1997) Dimensions of brand personality, Journal of Marketing Research; 34 (3); pg. 347-356.

Ahmad, A. K. S. dan Thyagaraj. (2014), Applicability of Brand Personality Dimensions Across Cultures And Product Categories: A Review. Global Journal of Finance and Management. ISSN 0975-6477 Volume 6, Number 1 (2014), pp. 9-18 economic, warmth, attention and sentimentality, which makes a brand is not only have an identity, but also has a human soul and personality that is aggressive, feminine, masculine, active, cheerful, and many others. Differences in personality dimensions may be influenced also by different cultural factors in each country, this case makes Bosnjak et al. (2007) build brand personality dimensions specific to a country.

Arora, Raj and Charles Stoner, (2009), A mixed method approach to understanding brand personality, Journal of Product \& Brand Management 18/4, 272-283.

Avis, Mark., (2012), Brand personality factor based models: A critical review, Australian Marketing Journal 20, 89-96.

Azoulay, A . and Kapferer , J . N . (2003) Do brand personality scales really measure brand 
personality? Journal of Brand Management 11 (2) : $143-155$.

Bosnjak, M ., Bochmann, V . and Hufschmidt, T . (2007) Dimensions of brand personality attributions: A person-centric approach in the German cultural context . Social Behavior and Personality 35 (3) : 303 - 316.

Caprara , G . V ., Barbaranelli , C . and Guido , G . (2001) Brand personality: How to make the metaphor fit? Journal of Economic Psychology 22 (3) : 377 - 395.

Fournier, S. (1994), Consumer And Their Brands: Develop Ing Relationship Theory In Consumer Research, Journal of Consumer Research, Vol. 24, March, pp 343-373

Geuens, Maggie., Bert Weijters and Kristof De Wulf, (2009), A new measure of brand personality, Intern. $\mathrm{J}$ of Research in Marketing 26: 97-107.

Guzman, Fransisco and Vicenta Sierra (2009), A Political candidate's brand image scale: Are political candidates brand?, Brand Management, Vol. 17.3.207-217.

Jana, Sudipto., Jyoti Ranjan Das, Manoranjan Dash, (2014), Modeling Brand Personality Using Structural Equation Modeling, IJMT, Vol. 4 Issue 8, ISSN: 2249-1-58.

Keller, Kevin Lane. (1993), Conceptualizing, Measuring, and Managing Customer-Based Equity, Journal of Marketing, Vol. 57, No. 1, Jan., pp. 1-22.
Kapferer, Jean Noel. (2008), The New Strategic Brand Management : Creating and Sustaining Brand Equity Long Term. 4thed. Kogan Page, London and Philadelphia

Milas, Goran and Boris Mlacic, (2007), Brand personality and human personality: Findings from ratings of familiar Croation brands, Journal od Business Research 60, 620-626.

Muniz, Karlan Muller and Renato Zancan Marchetti, (2012) Brand personality dimensions in the Brazilian context, BAR, Rio de Janeiro, v. 9, n. 2, art. 3, pp. 168-188.

Siavoshani, Emeliya Ghorbani, et.al., (2014), A study on the effects of service quality on brand personality: Evidance from Hotel Industry, Management Science Letters 4, 1547-1550.

Sung, Yongjun. and Jooyoung Kim, (2010), Effects of Brand Personality on Brand Trust and Brand Affect, Psychology \& Marketing, Vol. 27 (7): 639-661.

Sweeney, Jillian C. and Carol Brandon, (2006), Brand Personality: Exploring the Potensial to Move from Factor Analytical to Circumplex Models, Psychology \& Marketing, Vol. 23 (8): 639-663.

Yong-Ki Lee, Ki-Joon Back and Jin-Young Kim.(2009), Family Restaurant Brand personality and Its Impact On Customer's Emotion, Satisfaction, and Brand Loyalty. Journal of Hospitality \&amp; Tourism Research 33; 305 